Zdzistaw ŚLIWA

Baltic Defence College

zdzislaw.sliwa@baltdefcol.org

ORCID 0000-0002-5653-2941

https://doi.org/10.34739/dsd.2021.01.02

\title{
CHALLENGES FOR THE LAND CORRIDORS OF THE 'ONE BELT, ONE ROAD’ PROJECT
}

\begin{abstract}
The paper aims to analyse the status and challenges related to the land corridors of the visionary 'One Belt, One Road' concept promoted by China. Its importance is connected with the global reach creating enormous opportunities for involved nations, and the thesis is that it will continue although there are significant obstacles to specific land corridors. The paper utilises qualitative research based on official documents and data related to the project applying analysis, critical synthesis, desk research, and comparative studies methods. Quantitative data are used only for case studies. The paper will allow comprehending the respective corridors and the whole project concerning security and corresponding nations' interests.
\end{abstract}

KEYWORDS: One belt, One road', China, trading economies, security

\section{WYZWANIA WOBEC KORYTARZY LĄDOWYCH PROJEKTU 'JEDEN PAS, JEDNA DROGA'}

\begin{abstract}
ABSTRAKT: Celem artykułu jest analiza stanu oraz wyzwań związanych z korytarzami lądowymi promowanej przez Chiny, wizjonerskiej koncepcji „Jeden pas, jedna droga”. Jej znaczenie wiąże się z globalnym zasięgiem, stwarzając duże możliwości rozwoju zaangażowanych państw. Ocenia się, że projekt będzie kontynuowany, mimo że istnieją poważne przeszkody w relacji do poszczególnych korytarzy lądowych. W artykule wykorzystano badania jakościowe w oparciu o dostępne oficjalne dokumenty i dane związane z projektem stosując metody analizy, syntezy, analizy danych zastanych i badań porównawczych. Dane ilościowe wykorzystano w odniesieniu do studium przypadków. Artykuł umożliwi percepcję stanu i problemów w relacji do poszczególnych korytarzy lądowych oraz całej koncepcji w zakresie bezpieczeństwa i interesów narodowych.
\end{abstract}

SŁoWA KLUCZOWE: 'Jeden pas, Jedna droga', Chiny, wymiana handlowa, bezpieczeństwo

\section{INTRODUCTION}

The world's economic situation is evolving rapidly, being a factor within the competition between countries and companies. There are continuously new developments influencing all domains of human activities, affecting regions and continents. Currently, there is a consensus that rapidly progressing Asia, compared to the past, with China and India in the lead, is constantly impacting regional and global economies. During the last decades, the US shift toward Asia - Pacific region due to China's growing power in many domains was founded on 
recognising it as a competitor in a multilateral world. The fact is that the Chinese economic growth influences other nations as Foreign Direct Investments (FDI) and flow of goods and services. It could be a soft power factor also "economic resources are crucial to hard power"; therefore, trade relationships "can influence behaviour through hard- power rewards and punishment." It is causing opportunities, reservations and suspicions, which are not easy to overcome.

The paper aims to analyse the One Belt, One Road (OBOR) concept as an essential economy-related venture forwarded by China. The project has been developed along sea and land transportation corridors relying on Chinese global ambitions and funds but requiring involved nations' security stability and capacities. This initiative covers a few continents, but although demanding to complete, it is worth an effort, as the new logistics' chains will create enormous opportunities for all contributors. In essence, China and its evolving national economy model, FDI, and utilisation of national instruments of power are utilised to enhance relations with smaller nations within a 'soft power' approach while denying other competitors to do so. The paper will focus on the $O B O R$ land corridors and their status, challenges, and prospects.

The thesis is that the project is unstoppable and too crucial for China, especially for the Communist Party of China (CPC). It will be financed and continued; however, it will doubtfully meet the expected capacity before 2049 as of the limitations experienced by the project partners; even the current COVID-19 pandemic is a showstopper. The paper is based on qualitative research utilising available official documents and data related to the $O B O R$ project, applying analysis, critical synthesis, desk research, and comparative studies methods. Quantitative data are used only concerning case studies. The article will consist of an introduction and three main chapters to discuss the project background and current status. Next, it will cover land corridors linking China with South-East Asia, Europe, and beyond as case studies to highlight their importance for trade and possible future development problems. It will allow concluding the paper with respect to the purpose and thesis of the article.

\section{'One Belt, One Road' THe Background, Status, ChallengeS}

Xi Jinping's election as the President of the People's Republic of China (PRC) in March 2013 caused a new impetus in forwarding national ambitions expressed by his motto: 'Chinese Dream' (Chin. Zhongguomeng). It was linked to investments into the internal market and the facilitation of Chinese FDIs. The concept was based on four steps (Chin. si ge quanmian): creating a prosperous society or a stronger middle class (Chin. xiaokang shehui), a green and

\footnotetext{
${ }^{1}$ B.I. Page, T. Xie, The Complexities of Economic Soft Power: The U.S.-China Case, in S. Jong Lee, J. Melissen (eds.), Public Diplomacy and Soft Power in East Asia, Palgrave Macmillan Series in Global Public Diplomacy, New York 2011, p. 224.
} 
innovative economy, fight against corruption and enhancing the rule of law. ${ }^{2}$ In support, the National Security Commission (NSC) was created to promote proactive foreign policy ${ }^{3}$, strengthening China's role both regionally and globally. It is based on the assumption that "future growth will depend heavily on the degree of the Asia-Pacific region's integration with China's economy, as well as issues related to global economic governance and international trade rules." 4 The $O B O R$ project was adopted during the $18^{\text {th }}$ CPC National Congress in November 2012, presenting a 'New Silk Road' through Central Asia to Europe, a 'Silk Road on Sea' towards the Arabian Sea and 'an 'Economic Corridor' connecting India, Myanmar and Bangladesh." ${ }^{\prime 5}$ In December 2014, President Xi described it as one of China's future priorities ${ }^{6}$ and a vital element of the national strategy connected with the Look West program to enhance the Central and West provinces' development. The Global Times labelled it as a win-win megaproject in the context of regional cooperation and integration by means of infrastructure projects within Asia, Europe, and Africa ${ }^{7}$ using land corridors, which are relatively complex undertakings, covering regions and nations, which are different in many aspects. Some nations, e.g. Japan and South Korea, see them as an aggressive endeavour to dominate Asia. Economic success is central for CPC to facilitate integration with the worldwide economy, extend global order, and further develop cooperation with countries seeking economic support. $O B O R$ has proved to be important for Xi to underpin the desire to "take global leadership." ${ }^{\prime 8}$ Next, China's better business and political connections with neighbouring nations could serve national security ${ }^{9}$ and international cooperation, by "equal emphasis to 'bringing in' and 'going global", will extend "links running eastward and westward, across land and over the sea." 10 The project is supported by the Asian Infrastructure Investment Bank (AIIB), having 103 members

\footnotetext{
2 B. Góralczyk, Nowa strategia Chin: kłopot dla USA - czy calego świata? Wirtualna Polska, 13 April 2015, https://wiadomosci.wp.pl/nowa-strategia-chin-klopot-dla-usa-czy-calego-swiata-6025268413297281a (5.11.2020).

${ }^{3}$ L. Qin, Securing the "China Dream": What Xi Jinping wants to achieve with the National Security Commission (NSC), China Monitor No 4, 24 February 2014, p. 5.

${ }^{4}$ T. Hetah, Xi's Bold Foreign Policy Agenda: Beijing's Pursuit of Global Influence and the Growing Risk of Sino-U.S. Rivalry, China Brief Volume 15 Issue 6, 19 March 2015, http://www.jamestown.org/programs/chinabrief/single/ ?tx_ttnews\%5Btt_news\%5D=43674\&cHash=cd89a67fc61159ee2f89cbd44f361102\#.VrJSpO9f2Ag (4.11.2020).

${ }^{5} \mathrm{~S}$. LeVine, China is building the most extensive global commercial-military empire in history, Whitney and Betty MacMillan Center for International and Area Studies at Yale Global 9 June 2015, http://qz.com/415649/china-isbuilding-the-most-extensive-global-commercial-military-empire-in-history/ (5.11.2020); L. Qin, op. cit., p. 5.

${ }^{6}$ M. Li, China's "One Belt, One Road” Initiative: New Round of Opening Up? the S. Rajaratnam School of International Studies (RSIS), Multilateral Matters issue 15 April 2015, Singapore 2015, p. 1-2.

${ }^{7}$ M. Kaczmarski, Nowy Jedwabny Szlak: uniwersalne narzędzie chińskiej polityki, Ośrodek Studiów Wschodnich, Warsaw 10 February 2015, http://www.osw.waw.pl/pl/publikacje/komentarze-osw/2015-02-10/nowy-jedwabnyszlak-uniwersalne-narzedzie-chinskiej-polityki (6.11.2020).

${ }^{8}$ B. Goh, J. Ruwitch, Pressure on as Xi's 'Belt and Road' enshrined in Chinese party charter, Reuters 24 October 2017, https://www.reuters.com/article/us-china-congress-silkroad-idUSKBN1CT1IW (9.11.2020).

${ }^{9}$ Ibidem, p. 5.

${ }^{10}$ Full text of Xi Jinping's report at 19th CPC National Congress, Xinhua 4 November 2017, Para V.6 'Making new ground in pursuing opening up on all fronts'.
} 
worldwide ${ }^{11}$; its second-largest shareholder is India. ${ }^{12}$ Next, the Silk Road Fund (SRF) provides funds along with private Chinese enterprises within the Energy Development Fund. ${ }^{13}$

Silk Roads' land corridors run through a few regions like Central Asia, Iran, Turkey, Russia, and branches will cover Pakistan. However, many nations face internal and international challenges hampering trade continuity. It is connected with instability, regional disputes, terrorism and limited infrastructure. It is not excluding China as the fragile Xinjiang Uyghur Autonomous Region, as the land links with Central Asia and beyond with $45 \%$ of Uyghurs population. It has different religion (Islam), culture, and history fuelled by radical ideas promoting independence and Pan-Turkism. Therefore, Xinjiang's "will constrain Beijing's most ambitious visions of trans-Eurasian road, rail and pipeline systems"14 by terrorism acts by radical movements. Next to local attacks, those target Chinese economic interests in other nations and regions like Central Asia. ${ }^{15}$ Beijing's advantage is that Central Asian leadership is afraid of Uyghur's radicalism, so land economy corridors could help overcome threats and recognise $O B O R$ economic profits.

Moreover, China skilfully uses more "carrots" than 'sticks"” economic diplomacy. ${ }^{16}$ It is supported by security-related military cooperation within the Shanghai Cooperation Organization ${ }^{17}$ and Chinese ${ }^{18}$ funds to enhance the respective nations' ability to increase land corridors' capacity. The Xinjiang case is the visualisation of challenges to these transboundary and international land corridors.

\section{‘ONe Belt, One RoAD’ LANDLINES - CASE STUdies}

Recognising the complexity of land corridors' security, China is extending political and economic relations with countries such as Myanmar, Bangladesh, Pakistan, and India based on bilaterally beneficial cooperation. Such joint efforts and teamwork will positively influence trade-related security to achieve profits from trade and income from transit. The main trade

\footnotetext{
${ }^{11}$ What is the Asian Infrastructure Investment Bank? the Website of the Asian Infrastructure Investment Bank, http://www.aiib.org/html/aboutus/AIIB/ (accessed on 6 November 2020).

12 G. Sachdeva, Indian Perceptions of the Chinese Belt and Road Initiative, International Studies Vol 55 No 4 , October 2018, p. 289.

${ }^{13}$ W. Hu, New fund initiated for Silk Roads, the Global Times, 25 January 2015, http://www.globaltimes.cn/ content/903900.shtml (6.11.2020).

14 China's Ambitions in Xinjiang and Central Asia: Part 1, STRATFOR 30 September 2013, http://www.stratfor.com/analysis/chinas-ambitions-xinjiang-and-central-asia-part-1 republished with permission of Stratfor (5.11.2020).

${ }^{15}$ N. Swanström, Traditional and Non-Traditional Security Threats in Central Asia: Connecting the New and the Old, China and Eurasia Forum Quarterly, Volume 8, No. 2/2010, pp. 35 - 51.

16 J. Wong, China's Rising Economic Soft Power, Asia Research Institute 25 March 2016, https://theasiadialogue.com/2016/03/25/chinas-rising-economic-soft-power/ (7.11.2020); Z. Saurbek, KazakhChinese Energy Relations: Economic Pragmatism or Political Cooperation? China and Eurasia Forum Quarterly, Vol. 6, No 1, Central Asia-Caucasus Institute \& Silk Road Studies Program 2008, p. 79- 93.

${ }^{17}$ Z. Śliwa, Kierunki rozwoju Szanghajskiej Organizacji Wspótpracy, National Defense Academy, Warsaw 2012, p. 21; A. Jarosiewicz, Chińskie tour de force w Azji Centralnej, Ośrodek Studiów Wschodnich, Warsaw 18 September 2013, http://www.osw.waw.pl/pl/publikacje/analizy/2013-09-18/chinskie-tour-de-force-w-azji-centralnej (7.11.2020).

${ }^{18}$ P. Stobdan, China - Russia, CIS and Central Asia, in M. Rasgotra (ed.), Contemporary China and the World, Observer Research Foundation, New Delhi 2011, p. 58.
} 
corridors are "the new Eurasia Land Bridge, China-Central Asia-West Asia Economic Corridor, the China-Pakistan Economic Corridor (CPEC) and the Bangladesh-China-IndiaMyanmar Economic Cooperation (BCIM), which directly affect India's economic and strategic linkages with these regions." ${ }^{19}$ It is extended by the Kunming - Singapore Rail Link (SKRL) rail network and the China-Mongolia-Russia Corridor and Maritime Silk Road (Figure 1). Next to the corridors mentioned above, the Belt and Road Initiative supports some 35 local and regional economic initiatives by facilitating direct connectivity and expanding the reach of trade and interregional traffic. ${ }^{20}$

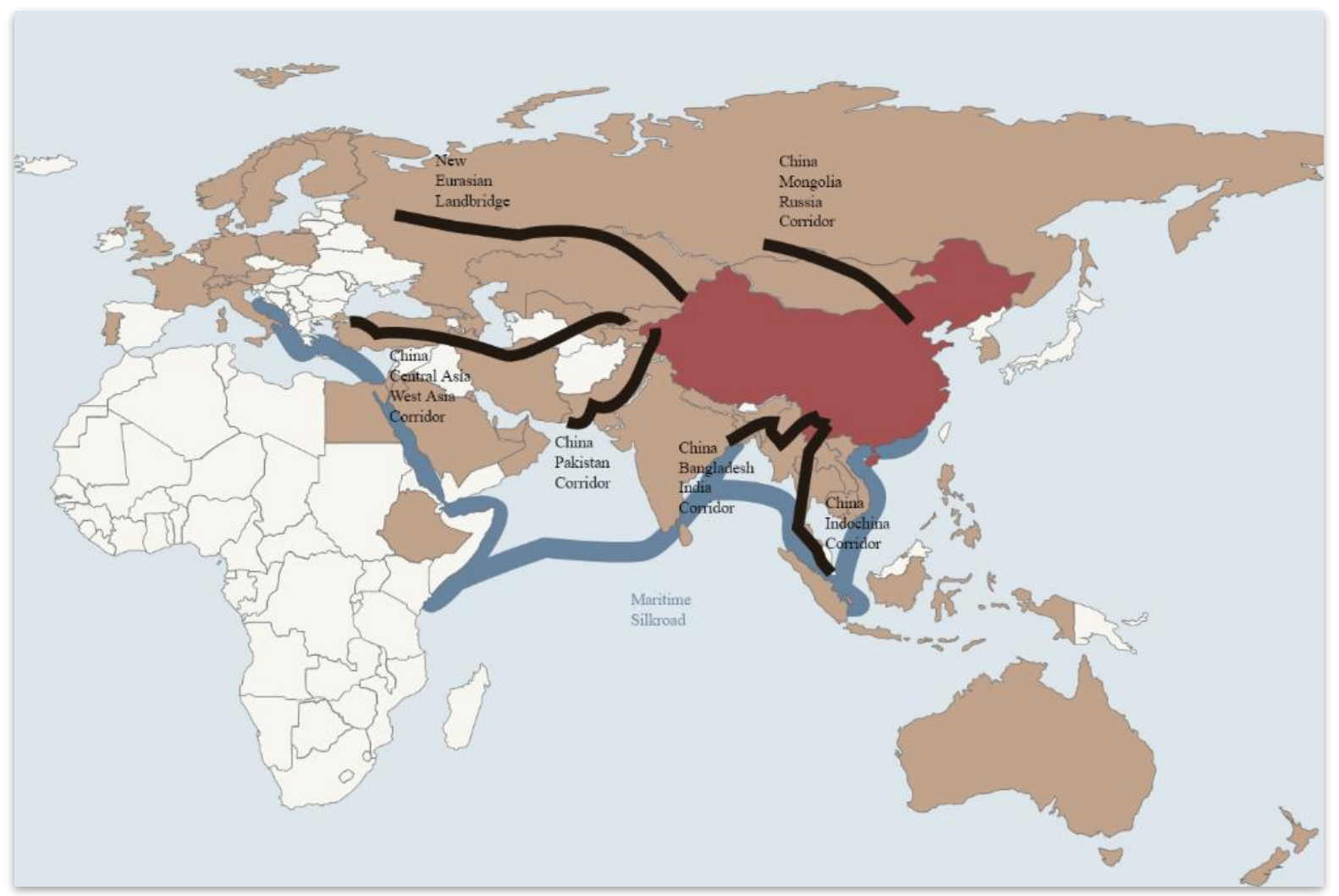

Figure 1. The concept of six Belt and Road corridors and Maritime Silk Road (China in red, AIIB members in orange) Source: Belt \& Road Provides Opportunities for Development, Belt and Road News 10 November 2020, https://www.beltandroad.news/2020/11/10/belt-road-provides-opportunities-for-development/ (7.11.2020).

The corridors will integrate China economically with nations in Southeast Asia, the Middle East, Europe, and beyond, making Beijing an attractive partner even for countries traditionally close to the US. It has happened even though some governments are afraid of growing Chinese military power and dominance ambitions in the shadow of the sea, water, borders and other disputes. Such an approach has been visualised when in 2016, the Philippines,

\footnotetext{
${ }^{19}$ G. Sachdeva, Indian Perceptions of the Chinese Belt and Road Initiative, op. cit., p. 286.

${ }^{20}$ Joint Communique of the Leaders' Roundtable of the 2nd Belt and Road Forum for International Cooperation, Beijing 27 April 2009, Annex.
} 
Malaysia, and Thailand joined the project, and in 2017, Singapore decided to enter through a bilateral free trade agreement and within the Regional Comprehensive Economic Partnership. ${ }^{21}$

\section{THE MAIN CORRIDORS OF THE ONE BELT, ONE ROAD. AN OVERVIEW}

The Kunming - Singapore Rail Link (KSRL) or Pan-Asia Railway Network was announced in 1999, initiated in 2006 to open gradually 6,617 km of high-speed rail between 2021- 2030, investing about USD 15 bln. It will have two central hubs (Kunming, Bangkok) and three routes ${ }^{22}$ :

- $\quad$ an eastern route from Kunming through Vietnam and Cambodia to Bangkok;

- a western route from Kunming through Myanmar to Bangkok; and

- a central route through Laos and Thailand to proceed southward to Singapore via Malaysia.

The project will link China (Kunming) with the Association of South-East Asian Nations (ASEAN), supporting cargo and passengers' movement and growing tourism, enriching societies in the region. The challenge is that some nations recognise Beijing policy as a potential threat to national security; some, e.g. Vietnam, are directly involved in islands' disputes, others are suspicious of Chinese minorities' intentions. ASEAN nations expressed the risks caused by China suggesting "to exercise self-restraint and avoid actions which would complicate the situation and undermine peace, stability, and security in the South China Sea and to settle disputes through peaceful means, without resorting to the threat or use of force." ${ }^{23}$ So, the bilateral political relations and security disputes between small and big economies are delaying joint projects. It is further complicated by US regional involvement. It is connected with the risk of being 'divided and conquered', as China possesses significant funds and tools to impact smaller ASEAN members. ${ }^{24} \mathrm{~A}$ factor is the diversity of nations partnering in the project and their ability to follow the requirements by providing funds, possessing proper technologies and ensuring political will. It is affected by other technical aspects such as different rail gauges, e.g. Thailand and Cambodia and many nations are in various stages of infrastructure investments causing unpredictability ${ }^{25}$; the military coup in Myanmar is an example. The combination of past relations and current suspicions will hamper the project, and multiple

\footnotetext{
${ }^{21}$ M. Esteban, The foreign policy of Xi Jinping after the 19th Congress: China strives for a central role on the world stage, Fundación Real Instituto Elcano 7 November 2017, http://www.realinstitutoelcano.org/wps/portal/ rielcano_en/contenido?WCM_GLOBAL_CONTEXT=/elcano/elcano_in/zonas_in/ari87-2017-esteban-foreign-policyxi-jinping-19th-congress-china-central-role-world-stage (8.11.2020).

22 Singapore-Kunming Rail Link (SKRL), Railway Technology 2020, https://www.railwaytechnology.com/projects/singapore-kunming-rail-link-skrl/ (10.11.2020).

${ }_{23}^{23}$ J. Hardy, Analysis: ASEAN finds voice over South China Sea dispute, IHS Jane's Defence Weekly, London 14 August 2014, http://www.janes.com/article/42006/analysis-asean-finds-voice-over-south-china-sea-dispute?utm_campaign $=[$ PMP]PC6110E14\%20DF\%20NL\%20SECURITY\%2008192014DWDeployment\&utmmedium=email\&utm_source= Eloqua (10.11.2020).

${ }^{24} \mathrm{~B}$. Schreer, S. Lee, The Importance of the Joint Statement on the US-ASEAN Strategic Partnership, the Diplomat 26 November 2015, http://thediplomat.com/2015/11/the-importance-of-the-joint-statement-on-the-us-aseanstrategic-partnership/ (7.11.2020).

${ }^{25}$ S. Ganjanakhundee, Completion of high-speed Southeast Asian rail link is still far down the track, The Nation Thailand 21 January 2018, https://www.nationthailand.com/ann/30336801 (7.11.2020).
} 
limitations within ASEAN partners will be another issue necessary to struggle bilaterally and within this organisation.

The Bangladesh-China-India-Myanmar Economic Cooperation (BCIM) corridor was initiated in 2015 with an initial USD 25bln estimated to boost the intraregional trade and contribute to peace and security in the region, based on mutual benefits. The study by Research and Information System for Developing Countries in India estimated the trade potential to reach even USD 132bln. ${ }^{26}$ The hindering factor could be cooperation among all four governments, their banking systems, access to markets, non-tariff barriers and inadequate infrastructure. The political factor is another challenge, especially between China and India; the latter was invited to join it during the borders delimitations talks in 2014. There were assessments that cooperation could be profitable in support of the Indian Prime Minister projects Make in India and Act East Policy. ${ }^{27}$ However, the partnership was harmed based on an estimate that it will disturb India's economic and strategic "linkages with these regions."28 The concept could serve New Delhi to improve relations with Beijing, enhance relations with Bangladesh, and finally not be left behind China in extending cooperation regionally, especially seeing Beijing as a competitor. Both nations are regional powers with global ambitions, so any peaceful undertaking supports positive relations, but it could be harmed any time, heavily delaying BCIM. India decided to miss the Belt and Road Forum (BRF) in April 2019, causing BCIM cancellation from the $O B O R$ list as a result of concerns about the China-Pakistan Economic Corridor (CPEC). However, the Chinese Foreign Ministry spokesperson explained that the BCIM is not cancelled and will be implemented ${ }^{29}$, but it could be only three nations venture. Still, India could revise the approach based on an economic calculus. China, utilising BCIM (or maybe BCM), is building up economic relations with Myanmar and Bangladesh, "exacerbating the endless Sino-Indian rivalry." 30 It is founded by a suspicion that China wants to dominate Asia and marginalise India, which is not acceptable for New Delhi, especially as Beijing drew corridors independently. ${ }^{31}$

The 1,125mile-long bullet train of the China-Pakistan Economic Corridor (CPEC) will start in Kashgar, through Pakistan will reach Gwadar, and the Arabian Sea harbours $^{32}$ (Figure 2) supporting Pakistan by investing USD $46 \mathrm{bln}^{33}$ into power plants,

\footnotetext{
26 S. Khan, A thriving economic belt in the making, The Financial Express 12 November 2020, https://thefinancialexpress.com.bd/views/a-thriving-economic-belt-in-the-making-1604159915 (7.11.2020).

27 H. Chandak, China's Grand Project - One Belt One Road, Swarajya Magazine 18 June 2015, http://swarajyamag.com/world/chinas-grand-project-one-belt-one-road/ (5.11.2020).

${ }^{28}$ G. Sachdeva, Indian Perceptions of the Chinese Belt and Road Initiative, op. cit., p. 286.

29 China denies abandoning BCIM Corridor, Belt and Road News 11June 2019, https://www.beltandroad.news/2019/06/11/china-denies-abandoning-bcim-corridor/ (8.11.2020).

${ }^{30}$ G. Gabusi, China's Structural Power and the Fate of the BCIM Economic Corridor, the International Spectator Vol 55 No 3/July 2020, pp. 31-32.

31 K. Sibal, The Belt and Road forum: India hits the nail, Indian Defence Review 7 June 2017 http://www.indiandefencereview.com/the-belt-and-road-forum-india-hits-the-nail/ (6.11.2020).

${ }^{32}$ S. LeVine, op. cit.

${ }^{33}$ Ibidem.
} 
highways or wind farms and solar parks. Additionally, it will expand Xinjiang prosperity to edge violence by generating employment opportunities causing "it more difficult for groups such as ETIM to thrive," ${ }^{34}$ limiting radicals' safe havens and training camps in Pakistan. Further development of CPEC is beneficial as Islamabad is parallel cooperating with China, and the US is trying to exploit those relations to fight Pakistan based extremist movements, especially in Baluchistan, where CPEC related Gwadar seaport is located. Islamabad is also accusing New Delhi of supporting terrorism in Baluchistan, and this factor further complicates the future of CPEC and BCIM. The security situation endangers the Pakistani leg's reliability and lack of stability, questioning the guarantees that investments will pay off.

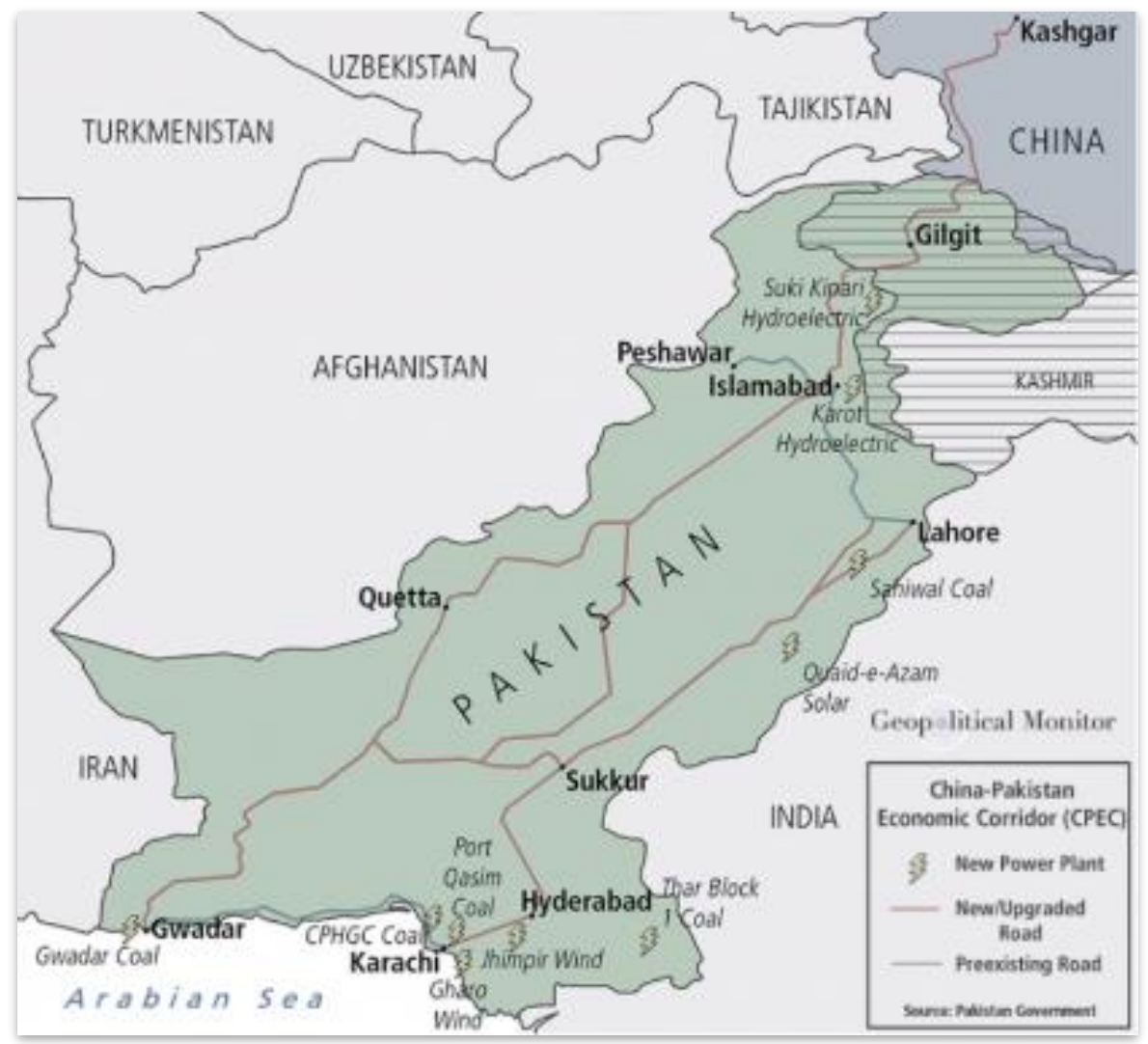

Figure 2. China - Pakistan Economic Corridor

Source: The China-Pakistan Economic Corridor (CPEC) Turns Five, Geopolitical Monitor 27 July 2020, https://www.geopoliticalmonitor.com/fact-sheet-china-pakistan-economic-corridor-cpec/ (7.11.2020).

Next, the infrastructure could become terrorist and separatists' target to directly hit the Pakistani government and economy. Such the complexity of threats creates significant questions toward investments, even though China and Pakistan believe that their cooperation will serve "regional and global peace, stability, and development." ${ }^{35}$ It was a matter of

\footnotetext{
${ }^{34}$ ETIM - East Turkestan Islamic Movement. T. Craig, S. Denyer, From the mountains to the sea: A Chinese vision, a Pakistani corridor, the Washington Post 23 October 2015, https://www.washingtonpost.com/ world/asia_pacific/from-the-mountains-to-the-sea-a-chinese-vision-a-pakistani-corridor/2015/10/23/4e1b6d302a42-11e5-a5ea-cf74396e59ec_story.html (8.11.2020).

${ }_{35}$ China, Pakistan sign treaty for friendship, cooperation and good-neighborly relations, People Daily, Pekin 6 April 2005, http://english.peopledaily.com.cn/200504/06/eng20050406_179629.html (7.11.2020).
} 
discussion during the then President Nawaz Sharif visit to Beijing in November 2014, who promised to unite efforts to fight Islamic movements. ${ }^{36}$

The CPEC is further complicated by the fragile situation in Kashmir and trilateral security challenges involving India and China directly, especially as all three nations possess a nuclear weapon. Therefore, only the normalisation of relations and cooperation could support the CPEC. India expresses the political dissatisfaction as:

the inclusion of the so-called China-Pakistan Economic Corridor (CPEC), which passes through parts of the Indian state of Jammu \& Kashmir under illegal occupation of Pakistan, as a flagship project of OBOR reflects the lack of appreciation of India's concerns on the issue of sovereignty and territorial integrity. ${ }^{37}$

Clashes between Indian and Chinese troops in disputed Ladakh in Kashmir in June 2020 are not supporting any cooperation; the memories of the 1962 Sino-Indian War are still alive. Next, India believes that "China has always used Pakistan as a proxy" 38 to contain it strategically. Additionally, the CPEC is linked to BCIM as its development will put at risk both corridors shrinking the Belt and Road Initiative's reach.

China - Central Asia - West Asia Economic Corridor (CCAWEC) runs from the fragile Xinjiang through Central Asian to the Persian Gulf, the Mediterranean Sea and the Arabian Peninsula. It connects 23 nations and is extending further; the first China Railways Express made a trip in November 2019 from China (Xian) through Kazakhstan, Azerbaijan, Georgia, Turkey (over Marmaray Tunnel under the Bosporus) to reach Czech Republic (Prague) in 18 days. The number of nations involved is complicating the project asking for many bilateral and multilateral agreements. The countries are different in many dimensions: religion, history, political systems and ongoing struggles, e.g. in the Nagorno-Karabakh or the conflict between Russia and Georgia. The Caucasus is vital for the corridor, but it is a fragile hot spot. The open question is if CCAWEC could support downgrading tensions, but it will surely enhance the Chinese footprint in the involved nations, although it is not easy to achieve. The construction of joint and mutually dependent communication lines is the primary security and stability related encounter. Therefore, the project will be one of the most challenging among all six. There is another potential advantage of the CCAWEC extension. It has already reached, e.g. the New Suez Canal/Corridor enhanced by the China-and Egypt TEDA Suez Economic and Trade Cooperation Zone as the part of the maritime leg within Sino-Egyptian cooperation. ${ }^{39} \mathrm{~A}$ vital player has become Iran, recognising the offered profits based on a USD 600bln economic agreement between Presidents Xi and Rouhani. ${ }^{40}$

\footnotetext{
${ }^{36}$ F. Bokhari, China pressures Pakistan to crack down on Uighur separatists, IHS Jane's Defence Weekly, 13 November 2014.

${ }^{37}$ G. Sachdeva, Indian Perceptions of the Chinese Belt and Road Initiative ..., op. cit., pp. 287-288.

${ }^{38}$ K. Sibal, The Belt and Road forum..., op. cit.

${ }^{39}$ China, Egypt join hands to write new chapter of Suez Canal development, Xinhua, China Daily 18 November 2019, https://www.chinadaily.com.cn/a/201911/18/WS5dd23667a310cf3e355781bf.html (9.11.2020).

40 First 'Silk Road' train arrives in Tehran from China, Mail Online 15 February 2016, http://www.dailymail.co.uk/wires/afp/article-3447907/First-Silk-Road-train-arrives-Tehran-China.html (6.11.2020).
} 
China-Mongolia-Russia Economic Corridor (CMREC) combines rail links and steppe roads to enhance the three nations' infrastructure limiting transportation time and support agriculture, tourism, and the natural environment. ${ }^{41}$ Furthermore, the four transport routes will improve the connection with Pacific seaports (Tianjin, Vladivostok) and shorten Russian freight routes through Mongolia. The network will enable the exploration of the Eastern Siberia and Mongolian natural resources desired by all partners. It is a real opportunity for Mongolia but requires China's investments, which is "consuming more than $80.0 \%$ of Mongolian exports and a source of about $1 / 3$ of total imports." 42 The cooperation is enhancing CMREC importance and supports Beijing interest in Siberian gold, ore and coal deposits. ${ }^{43}$ For Mongolia, as a landlocked country, it is an opportunity as transportation links and easier access to seaports will support national prosperity. Ulaanbaatar has no potential to complete projects alone, so the partnership with two more powerful nations, although having an element of risk, is an opportunity. Among them, Ulan Bator will need to "balance its engagement with Russia against its engagement with China, without alienating one or the other." 44 The poor mining and logistical infrastructure and limited transboundary industrial cooperation are the significant obstacles requiring AIIB investments. Close cooperation is vital, but Russian and Chinese aspirations could hinder it in the long-term, as the latter could see CMREC as a useful tool to impact two other CMREC partners. ${ }^{45}$

New Eurasian Land Bridge (NELB) or the Second Eurasian Continental Bridge connects the Pacific and Atlantic with a 10,800-km-long rail link associating some 30 countries running via Kazakhstan, Russia, Belarus, Poland, Germany and further West. ${ }^{46}$ Several transcontinental rail routes are operational, reaching even Spain. It is a complex venture requiring respective nations' involvement and international organisations such as the European Union (EU), the Eurasian Economic Union, and regional ones such as Visegrad Four, causing negotiations to be more complicated. The tensions in Europe, e.g. the Russia and Ukraine conflict and unstable Belarus, are security challenges that are not to be overcome quickly. There are also technical problems like limited infrastructure for the extended volume of cargo and some bottlenecks caused by different gauge size between Belarus and Poland. The NELB is a "political challenge, but it is important to recognise the solid economic foundations, as rail

\footnotetext{
${ }^{41}$ Программа Создания Экономического Коридора Китай - Монголия - Россия, Ташкент 23 июня 2016.

${ }^{42}$ A. Andreev, V. Makarov, The routes of the Mongolian economic corridor: development prospects, transport and logistics constraints, IOP Conference Series: Earth and Environmental Science 2019, pp. 1-2.

${ }^{43}$ Ibidem, p. 2.

44 A. Graceffo, Mongolia and the Belt and Road Initiative: The Prospects for the China-Mongolia-Russia Economic Corridor, The Jamestown Foundation China Brief Vol. 20, Issue 12, 15 July 2020, p. 39.

${ }^{45}$ Б. А. Красноярова, Стратегическая Инициатива Китая - «Одна Дорога - Один Путь» - Инструмент Развития Или Алгоритм Воздейсвтия На Горные Регионы Центральной Азии, in: Экономический Коридор «Китай-Монголия-Россия»: Географические и Экологические Факторы и Возможности Территориального Развития, Ministry of Science and Higher Education August 2018, p. 186.

46 Six Major Economic Corridors under Belt \& Road Initiative, Belt and Road News 16 April 2020 , https://www.beltandroad.news/2020/04/16/six-major-economic-corridors-under-belt-road-initiative/ (12.11.2020).
} 
offers a competitive service in terms of reliability that is faster than sea and cheaper than air." $" 47$ Nevertheless, it could support nations integrating them by trade exchange and strengthening Asian and European relations within the trade and security domain. The EU shares such the perception within Connecting Europe \& Asia: The EU Strategy as "Europe and Asia, together, can be the engines of a more cooperative approach to world politics, global stability and regional economic prosperity." 48 It could be achieved, among others, by integrating NELB with Trans-European Network for Transport (TEN-T), joint investments, institutional and financial frameworks, and mutual understanding among societies. It is in line with other EU regional transportation projects, such as 'Rail Baltica' and 'Via Baltica' to be connected in the future with 'Via Carpathia'. In this context, Europe is a reliable and desired partner; the challenge is to reach those West networks through less reliable partners.

\section{CONCLUSIONS}

The progress of all corridors, even slower lately, is ongoing even during the pandemic based on political will and economic support. For Beijing, it will support one of the two centenary goals or Liang ge yibai nian to mark in 2049 the 100th anniversary of China by "building a modern socialist country that is prosperous, strong, democratic, culturally advanced and harmonious." ${ }^{49}$ US role and regional tensions could delay Chinese trade corridors as Washington is pursuing the same markets as $O B O R$ with the International Finance Development Corporation (IDFC). ${ }^{50}$ The change of administration in the White House in January 2020 could impact the developments; recognising it Chinese leader has sent congratulations to President-Elect looking into future cooperation. International relations are connected with the rivalry between India and China, and it could significantly delay and limit the development of CPEC and BCIM. Similarly, if degraded, Russian - Chinese relations will affect CMREC with harm for all three involved nations. There is another face of the $O B O R$. It will be a pure business for some countries, especially for those with authoritarian governments, creating opportunities among politicians, businessmen, and local authorities to get profit or even for corruption. For other partners, like members of the EU, it will be a struggle between protecting organisational values and exploiting economic prospects.

Nevertheless, China's One Belt, One Road initiative will be continued, although the COVID-19 pandemic harmed some projects, but those will be reconsidered and continued as

\footnotetext{
${ }^{47}$ R. Pomfret, The Eurasian Landbridge: Implications of linking East Asia and Europe by rail, The University of Adelaide April 2020, pp. 6-7.

${ }^{48}$ Joint Communication to the European Parliament, the Council, the European Economic and Social Committee, the Committee of the Regions and the European Investment Bank. Connecting Europe and Asia - Building blocks for an EU Strategy, European Commission Brussels 19 September 2018, p. 1-2.

${ }^{49}$ Global China 2049 Initiative, Overseas Development Institute, https://www.odi.org/projects/china-2049initiative (6.12.2020).

${ }^{50}$ Trump Targets Belt and Road Initiative with US\$60 Billion International Finance Development Corporation, Silk Road Briefing 22 October 2019, https://www.silkroadbriefing.com/news/2019/10/22/trump-targets-belt-roadinitiative-us60-billion-international-finance-development-corporation/ (6.12.2020).
} 
the situation allows. The multi-nationality and legal regulations, e.g. for cross-boundary movement, will be the substantial obstacles, not easy to solve, causing delays (CCAWEC, NELB). One of the challenges are regional interstate conflicts and asymmetric threats, being the real danger impeding the flow of FDIs and the tempo of building infrastructure. It could hurt the economy of all countries involved in silk roads projects, and it will slow down international economic integration, which is critical for the flow of supplies meeting the expectations of importers and exporters. If it is not ensured, major global companies will terminate or even abandon the offered opportunities as investors could recognise the corridors as vulnerable and unreliable. Regional wars, conflicts, and disputes (CPEC, CCAWEC, BCIM) affect land corridors build-up as the significant investments are long-term, requiring stability to minimise economic risks. In sum, the Chinese project is an example of close interrelations between the security environment and trade processes, presenting that constant and close international cooperation could ensure the proper level of protection of export/import networks regionally and globally. All legs of $O B O R$, although using different roads and domains, are equally vulnerable and only the nature of threats or challenges is differing. Nevertheless, China has invested too much to discontinue One Belt, One Road, as it could be seen as Xi's personal disappointment affecting his and CPC long-term visionary 'Chinese Dream'.

\section{BIBLIOGRAPHY}

Andreev Andrey, Makarov Vladimir. 2019. The routes of the Mongolian economic corridor: development prospects, transport and logistics constraints, IOP Conference Series: Earth and Environmental Science: 1-2.

Bokhari Farhan. 2014. China pressures Pakistan to crack down on Uighur separatists, IHS Jane's Defence Weekly, 13 November.

Chandak Hemant. 2015. China's Grand Project - One Belt One Road. Swarajya Magazine 18 June. http://swarajyamag.com/world/chinas-grand-project-one-belt-one-road/.

China denies abandoning BCIM Corridor. 2019. Belt and Road News 11 June. https://www.beltandroad.news/2019/06/11/china-denies-abandoning-bcim-corridor/.

China, Egypt join hands to write new chapter of Suez Canal development. 2019. China Daily 18 November.

https://www.chinadaily.com.cn/a/201911/18/WS5dd23667a310cf3e355781bf.html.

China, Pakistan sign a treaty for friendship, cooperation and good-neighbourly relations. 2005. People Daily 6 April.

http://english.peopledaily.com.cn/200504/06/eng20050406_179629.html.

China's Ambitions in Xinjiang and Central Asia: Part 1. 2013. STRATFOR 30 September. http://www.stratfor.com/analysis/chinas-ambitions-xinjiang-and-central-asia-part-1.

China's Central Asia Problem, the International Crisis Group. 2013. Crisis Group Asia Report No 244, 27 February: 4. 
Craig Tim, Denyer Simon. 2015. "From the mountains to the sea: A Chinese vision, a Pakistani corridor". the Washington Post 23 October, https://www.washingtonpost.com/world/asia_pacific/from-the-mountains-to-the-sea-achinese-vision-a-pakistani-corridor/2015/10/23/4e1b6d30-2a42-11e5-a5eacf74396e59ec_story.html.

Esteban Mario. 2017. The foreign policy of Xi Jinping after the 19th Congress: China strives for a central role on the world stage. Fundación Real Instituto Elcano 7 November. http://www.realinstitutoelcano.org/wps/portal/rielcano_en/contenido?WCM_GLOBAL _CONTEXT=/elcano/elcano_in/zonas_in/ari87-2017-esteban-foreign-policy-xi-jinping19th-congress-china-central-role-world-stage.

First 'Silk Road' train arrives in Tehran from China. 2016. Mail Online 15 February. http://www.dailymail.co.uk/wires/afp/article-3447907/First-Silk-Road-train-arrives-

Tehran-China.html.

Full text of Xi Jinping's report at 19th CPC National Congress. 2017. Xinhua 4 November: Para V.6.

Gabusi Giuseppe. 2020. "China's Structural Power and the Fate of the BCIM Economic Corridor". The International Spectator Vol 55 (3): 31-32.

Ganjanakhundee Supalak. 2018. "Completion of high-speed Southeast Asian rail link is still far down the track". The Nation Thailand 21 January. https://www.nationthailand.com/ann/30336801.

Global China 2049 Initiative. Overseas Development Institute. https://www.odi.org/projects/china-2049-initiative

Goh Brenda, Ruwitch John. 2017. "Pressure on as Xi's 'Belt and Road' enshrined in Chinese party charter". Reuters 24 October. https://www.reuters.com/article/us-china-congresssilkroad-idUSKBN1CT1IW.

Góralczyk Bogdan. 2015. „Nowa strategia Chin: kłopot dla USA - czy całego świata?” Wirtualna Polska, 13 April, https://wiadomosci.wp.pl/nowa-strategia-chin-klopot-dlausa-czy-calego-swiata-6025268413297281a.

Graceffo Antonio. 2020. "Mongolia and the Belt and Road Initiative: The Prospects for the China-Mongolia-Russia Economic Corridor". The Jamestown Foundation China Brief Vol. 20 (2): 39.

Hardy John. 2014. “Analysis: ASEAN finds voice over South China Sea dispute”. IHS Jane's Defence Weekly, London 14 August. http://www.janes.com/article/42006/analysisasean-finds-voice-over-south-china-sea-

dispute?utm_campaign=[PMP]_PC6110_E14\%20DF\%20NL\%20SECURITY\%2008_1 9_2014_DW_Deployment\&utm_medium=email\&utm_source=Eloqua.

Hardy John. 2015. "DSEI 2015: Japanese, Chinese naval officers clash over South China Sea”. IHS Jane's Defence Weekly London 17 September, http://www.janes.com/article/54431/dsei-2015-japanese-chinese-naval-officers-clashover-south-china-sea.

Hetah Timothy. 2015. 'Xi's Bold Foreign Policy Agenda: Beijing's Pursuit of Global Influence and the Growing Risk of Sino-U.S. Rivalry". China Brief Volume 15(6): 
http://www.jamestown.org/programs/chinabrief/single/?tx_ttnews\%5Btt_news\%5D=43 674\&cHash=cd89a67fc61159ee2f89cbd44f361102\#.VrJSpO9f2Ag.

$\mathrm{Hu}$ Weijia. 2015. New fund initiated for Silk Roads, the Global Times, 25 January. http://www.globaltimes.cn/content/903900.shtml.

Jarosiewicz Aleksandra. 2013. "Chińskie tour de force w Azji Centralnej”. Ośrodek Studiów Wschodnich, Warsaw 18 September,

http://www.osw.waw.pl/pl/publikacje/analizy/2013-09-18/chinskie-tour-de-force-wazji-centralnej.

Joint Communication to the European Parliament, the Council, the European Economic and Social Committee, the Committee of the Regions and the European Investment Bank. 2018. Connecting Europe and Asia - Building blocks for an EU Strategy, European Commission Brussels 19 September: 1-2.

Joint Communique of the Leaders' Roundtable of the 2nd Belt and Road Forum for International Cooperation. 2009. Beijing 27 April: Annex.

Kaczmarski Marcin. 2015. "Nowy Jedwabny Szlak: uniwersalne narzędzie chińskiej polityki [The New Silk Road: a universal tool of Chinese politics]”. Ośrodek Studiów Wschodnich, Warsaw 10 February. http://www.osw.waw.pl/pl/publikacje/komentarzeosw/2015-02-10/nowy-jedwabny-szlak-uniwersalne-narzedzie-chinskiej-polityki.

Khan Shahiduzzaman. 2020. "A thriving economic belt in the making”. The Financial Express 12 November. https://thefinancialexpress.com.bd/views/a-thriving-economic-belt-inthe-making-1604159915

Lee Danny. 2015. Xinjiang, first hand. China Daily, 12 November. http://www.chinadaily.com.cn/china/60thxjannivesary/2015-

11/12/content_22443337.htm.

LeVine Steve. 2015. China is building the most extensive global commercial-military empire in history, Whitney and Betty MacMillan Center for International and Area Studies at Yale Global 9 June. http://qz.com/415649/china-is-building-the-most-extensive-globalcommercial-military-empire-in-history/.

Li Mingjiang. 2015. China's “One Belt, One Road” Initiative: New Round of Opening Up? The S. Rajaratnam School of International Studies (RSIS), Multilateral Matters Issue 15 April, Singapore: 1-2.

Nakazawa Katsuji. 2019. Trump spoils Xi's Belt and Road Forum, without even attending. Nikkei Asia 2 May. https://asia.nikkei.com/Editor-s-Picks/China-up-close/Trump-spoils$\mathrm{Xi-s-Belt-and-Road-Forum-without-even-attending.}$

Page Benjamin, Xie Tao. 2011. The Complexities of Economic Soft Power: The U.S.-China Case. In S. Jong Lee, J. Melissen (eds.). Public Diplomacy and Soft Power in East Asia, New York: Palgrave Macmillan Series in Global Public Diplomacy: 224.

Pomfret Richard. 2020. The Eurasian Landbridge: Implications of linking East Asia and Europe by rail. The University of Adelaide: 6-7.

Qin Liwen. 2014. "Securing the 'China Dream': What Xi Jinping wants to achieve with the National Security Commission (NSC)”. China Monitor No 4, 24 February: 5. 
Sachdeva Gulshan. 2018. "Indian Perceptions of the Chinese Belt and Road Initiative", International Studies Vol 55(4): 289.

Saurbek Zhanibek. 2008. "Kazakh-Chinese Energy Relations: Economic Pragmatism or Political Cooperation?" China and Eurasia Forum Quarterly, Vol. 6(1): 79- 93.

Schreer Ben, Lee Sheryn. 2015. The Importance of the Joint Statement on the US-ASEAN Strategic Partnership, the Diplomat 26 November, http://thediplomat.com/2015/11/theimportance-of-the-joint-statement-on-the-us-asean-strategic-partnership/.

Sibal Kanwal. 2017. The Belt and Road Forum: India hits the nail, Indian Defence Review 7 June. http://www.indiandefencereview.com/the-belt-and-road-forum-india-hits-the-nail/.

Singapore-Kunming Rail Link (SKRL). 2020. Railway Technology. https://www.railwaytechnology.com/projects/singapore-kunming-rail-link-skrl/.

Six Major Economic Corridors under Belt \& Road Initiative. 2020. Belt and Road News 16 April, https://www.beltandroad.news/2020/04/16/six-major-economic-corridorsunder-belt-road-initiative/.

Śliwa Zdzislaw. 2012. Kierunki rozwoju Szanghajskiej Organizacji Współpracy [Directions of Development of the Shanghai Cooperation Organization]. National Defense Academy, Warsaw.

Stobdan Phunchok. 2011. China - Russia, CIS and Central Asia. In Rasgotra Maharaja (ed.). Contemporary China and the World, Observer Research Foundation, New Delhi: 58.

Swanström Niklas. 2010. "Traditional and Non-Traditional Security Threats in Central Asia: Connecting the New and the Old". China and Eurasia Forum Quarterly, Volume 8 (2): 35 - 51.

Trump Targets Belt and Road Initiative with US\$60 Billion International Finance Development Corporation. 2019. Silk Road Briefing 22 October. https://www.silkroadbriefing.com/news/2019/10/22/trump-targets-belt-road-initiativeus60-billion-international-finance-development-corporation/.

What is the Asian Infrastructure Investment Bank? The Website of the Asian Infrastructure Investment Bank, http://www.aiib.org/html/aboutus/AIIB/ .

Wong John. 2016. China's Rising Economic Soft Power. Asia Research Institute 25 March. https://theasiadialogue.com/2016/03/25/chinas-rising-economic-soft-power/ .

Красноярова Бэлла Александровна. 2018. Стратегическая Инициатива Китая - «Одна Дорога - Один Путь» - Инструмент Развития Или Алгоритм Воздейсвтия На Горные Регионы Центральной Азии, in: Экономический Коридор «Китай-Монголия-Россия»: Географические и Экологические Факторы и Возможности Территориального Развития. Ministry of Science and Higher Education. [Krasnoyarova Bella Aleksandrovna. 2018. Strategicheskaya Initiyativa Kitaya - "Odna Doroga - Odin Put"' - Instrument Razvitiya Ili Algoritm Vozdeystva na Gornye Regiony Tsentralnoy Azii, In: Ekonomicheskiy Koridor "Kitay-Mongoliya-Rossiya": Geograficheskie i Ekologicheskie Faktory i Vozmozhnosti Territorial'nogo Razvitiya. Ministry of Science and Higher Education].

Программа Создания Экономического Коридора Китай - Монголия - Россия. 2016. Ташкент 23 июня [Programma Sozdaniya Ekonomicheskogo Koridora KitajMongoliya-Rossiya. 2016. Tashkent 23 iyunya]. 